IZA DP No. 6404

Public and Private Sector Jobs, Unreported Income and Consumption Gap in India: Evidence from Micro-Data

Saibal Kar

Poulomi Roy

Sarani Saha

March 2012 


\title{
Public and Private Sector Jobs, Unreported Income and Consumption Gap in India: Evidence from Micro-Data
}

\author{
Saibal Kar \\ Centre for Studies in Social Sciences, Calcutta \\ and IZA \\ Poulomi Roy \\ Jadavpur University \\ Sarani Saha \\ Indian Institute of Technology, Kanpur
}

Discussion Paper No. 6404

March 2012

IZA

P.O. Box 7240

53072 Bonn

Germany

Phone: +49-228-3894-0

Fax: +49-228-3894-180

E-mail: iza@iza.org

Any opinions expressed here are those of the author(s) and not those of IZA. Research published in this series may include views on policy, but the institute itself takes no institutional policy positions.

The Institute for the Study of Labor (IZA) in Bonn is a local and virtual international research center and a place of communication between science, politics and business. IZA is an independent nonprofit organization supported by Deutsche Post Foundation. The center is associated with the University of Bonn and offers a stimulating research environment through its international network, workshops and conferences, data service, project support, research visits and doctoral program. IZA engages in (i) original and internationally competitive research in all fields of labor economics, (ii) development of policy concepts, and (iii) dissemination of research results and concepts to the interested public.

IZA Discussion Papers often represent preliminary work and are circulated to encourage discussion. Citation of such a paper should account for its provisional character. A revised version may be available directly from the author. 


\section{ABSTRACT \\ Public and Private Sector Jobs, Unreported Income and Consumption Gap in India: Evidence from Micro-Data*}

This paper tries to document the presence of unreported income among public sector employees in India. We investigate empirically the wage gap as well as consumption expenditure parity between public and private sector workers. It tests the hypothesis that despite a lower level of public sector income in some of the quantiles, if the level of durable goods consumption between the private and the public sector employees are similar, then it might be indicative of the presence of unreported income among the public sector workers. The 2004-05 survey of income and consumption by workers in both private and public sectors (NSSO) supports presence of unaccounted for income among public sector employees at the uppermost quantile. The empirical part is followed by a generalized theoretical formulation that comes up with a measure of the equilibrium level of the unreported income earned by the public sector employees.

JEL Classification: C12, C31, D23, J21

Keywords: $\quad$ unreported income, consumption, indirect utility, quantile regression, India

Corresponding author:

Sarani Saha

Department of Humanities and Social Sciences

IIT Kanpur

Kanpur-208016

India

E-mail: sarani@iitk.ac.in

\footnotetext{
* We thank conference participants at Indian Statistical Institute, Delhi and Jadavpur University, Kolkata for many helpful comments. The usual disclaimer applies.
} 
1. Introduction

Corruption is widely seen as an obstacle to the process of development. It distorts prices and raises transaction costs leading to inefficiency in the system. The persistence of both petty and large-scale corruption is generally a consequence of poor rule of law, lack of transparency, accountability and regulations, but not restricted to these only. This makes measurement of corruption an extremely vexing exercise. We make an effort to measure the extent of corruption in the public sector. Our primary hypothesis is that consumption of durable commodities for certain groups are financed by income earned in the form of 'bribes'. 'Bribes', in our empirical and theoretical analyses serves as a generic form of undocumented income which confers a higher ability to consume, ceteris paribus. It is so because, additional purchasing power may come from unreported income (not amounting to bribes) including, but not limited to tax evasion, undocumented income from properties, capital gains as black money, or very differently from a lower propensity to save, higher discount rates, etc. ${ }^{1}$

Clearly, the sources of undocumented income are interlinked and it is very difficult to isolate the point of origin, empirically. ${ }^{2}$ The common perception is that certain groups, such as those in the public sector, accept bribes. It is also documented that non-public sector employees, such as those in the private sector at comparable positions to public sector officials (for example, the managers, CEOs, etc.) receive higher salaries, although, as we shall show, the wage gap is not monotonic across all positions. Everything else remaining same, it should then imply that for 'some' occupational types at least, consumption levels for

\footnotetext{
${ }^{1}$ In many developing countries only a small number of formal units offer post-retirement benefits, such as pension. The relatively large non-formal labor market does not provide standard social security benefits to the workforce (see for example, Tzannatos and Roddis, 1998).

${ }^{2}$ For example, a public official paying bribes to another public official to undervalue an asset or property for saving property taxes or registration charges.
} 
private sector workers should be higher than their public sector counterparts. Our empirical analysis investigates this hypothesis controlling for major sources of variations (such as job security, fringe benefits, pension provisions) that may potentially influence the correspondence between consumption gaps and wage gaps across public and private sector employees.

While India continues to be infamous for high levels of corruption in the public sector, the literature lacks credible analysis of its extent and depth. It is well known that public sector corruption in India has been historically facilitated by the so-called 'LicenseRaj' - a public instrument of economic control that epitomized the bureaucratic practice of red tapes and rent seeking (see for example, Saha 2000). Despite industrial and trade reforms carried out in the country since early 1990s and subsequent delegation of governance to the grass-root level, i.e. the village 'panchayat' (local decentralized governance with subprovincial political and economic authority $)^{3}$, the deep-seated phenomenon of greasing the palm for every economic activity continues. This motivates us to seek a comparison between private and public sector wages and additional income earned via bribes and how it affects consumption levels of the two groups. The empirical findings of our paper influence a brief but generalized theoretical formulation to offer a measure of the unaccounted for income level.

Essentially, both public and private sector employees display corrupt behavior in the Indian society where it concerns acceptance of bribes, kickbacks or tax evasion. We investigate if a gap exists between consumption levels of public and private sector employees in India and whether such difference is explained by the prevailing income gap (Glinskaya 
and Lokshin, 2007 documents public-private wage gap in India) between these two sectors.

We document a positive income gap at comparable positions, particularly in the upper tiers of occupation classifications, in favor of the private sector. It gets reversed for lower levels of occupational distribution, where public sector employees are better off due to provisions of minimum wages and other benefits. The job security generally seems much better for public sector workers in India. Thus, if employees in public sector earn lower wages than private sector workers at upper 'quantiles' and yet no perceptible difference in consumption level is observed, then it may hint at possibilities of additional unreported sources of income, ceteris paribus. The 'extra' income may come from interest bearing assets, investments, direct bequests, remittances, borrowings, etc. and 'bribes'. Our empirical section controls for some of these sources and investigates if 'unrecorded' bribes can explain the consumption pattern. ${ }^{4}$ In this regard, our intellectual debt to a recent study by Gorodnichenko and Peter (2007) on corruption in Ukraine should be emphasized. However, the data set for measuring corruption in India has many limitations compared to other country studies (viz. Dreher, et al. 2007; Johnson et al., 2000; Mocan, 2004; van Rijckeghem and Weder, 2001, etc).

Based on the empirical findings, we develop a theoretical model. It obtains the consumption levels of durable and non-durable goods for public and private sector workers from the direct utility functions. Our empirical result suggests that at the upper quantiles of income distribution, the private sector workers earn more and spend more on non-durable goods (accounting for living expenditures) than the public sector workers. However, expenditure on durable goods is not statistically different between these two groups. In most

\footnotetext{
${ }^{4}$ We do not think that pure imitation of a richer lifestyle is a tenable argument behind higher consumption expenditures among those earning lower income. On average, it is unlikely that a person with fixed life time income dis-saves or borrows and jeopardizes future consumption by consuming too much presently in order to imitate the consumption standard of a rich person.
} 
of the literature on permanent income and life cycle literature, it is argued that transitory income, in particular, is saved and distributed among all types of assets including durable goods. The response should be less for non-durable goods and services. However, according to Seater and Mariano (1985), it is much more sensible for the consumer to use transitory income for purchase of financial assets, which have low transaction costs and do not suffer from the usual 'storage' problem associated with purchase of durable goods while following an optimal consumption path over lifecycle. Presently, we expect that transitory income in the form of unreported earnings buys financial assets, real estate and gold, all of which have a tendency to appreciate in value over time. Furthermore, non-reported earnings or black money are often spent on social functions like marriages, birthday parties, anniversaries, etc. ${ }^{5}$

Finally, corruption in economic literature is looked at from two very different angles. According to various cross-country cultural practices, it is either seen as a phenomenon that 'greases the wheel' or that which 'sands the wheel' of economic development. India continues to be one of the most corrupt nations in the world with a Corruption Perception Score (compiled by the Transparency International) of 3.3 (out of 10, with 10 meaning the least corrupt case) in 2010. India's nature of corruption, mostly seen as political, is a clear reflection of poor governance in the country. In addition the incidence of petty corruption being rather high for India, there is a clear case for measuring its impact on income and consumption, as this paper offers.

The rest of the paper is organized as follows. Section 2 discusses the empirical

\footnotetext{
5 The Income Tax Department of India collects information on such social events from time to time under the IT Act, 1961, provision - s.133A (5). However, in recent years collection of such information falls far short of desired levels and it is argued that the high inflation in the country (at $15 \%$ approximately during 2011) is partly fueled by purchase and hoarding of consumer goods with the help of black money. http://www.indianexpress.com/news/use-of-black-money-reason-for-inflation-pri/780701/. Also see Singh (2008) for use of black money in India.
} 
results. Section 3 develops the models and section 4 concludes.

\section{Empirical Model and Results}

\section{Data Sources and Methodology}

The data we use are taken from unit level survey data on Employment and Unemployment situation in India. The National Sample Survey Organization (NSSO) in India conducts and publishes such data. The survey was carried out between July 2004 and June 2005. NSSO adopted a stratified multi stage design for the survey. Census villages of 2001 are used as the first stage units (FSU) for the rural sector and for the urban sector. The Urban Frame Survey blocks are used as FSUs. At the all India level 12,784 FSUs have been allocated for central sample and for 14,992 for the state sample. Households are ultimate stage units but some data at the individual level is also available.

Our analysis is based on data both at the individual as well as the household level. The variables that reflect individual level information are age, sex, education level, wages and salaries earned, having full-time or part-time employment, type of enterprises (public/private/unorganized), availability of social security benefits, paid leave eligibility, nature of job contract. Information on household size, total monthly expenditure on durable goods, total monthly consumption expenditure are available at the household level.

As argued earlier, we consider only those members who have worked as regular salaried/ wage employee. We divide this group then into three sub groups: (a) working in the government/public sector (b) working in the public/private limited company; and (c) working in 'other', namely the unorganized sector. Our empirical analysis is based on the members who are employed in any of these three categories. The total number of households 
considered is 7327 . Households with no wage income or missing wage data are not considered for analysis. The age group 15-60 years is considered as the working age group and the sample is restricted to this group only. Total number of wage earners within the working age group is 9786 . Household members of age less than 15 years are considered as child and those over 60 years of age are considered as out of the labor force.

At the household level, we have excluded those for which the primary source of income is self-employment (for both Rural and Urban regions). Table 1 provides the summary statistics of all variables used in our analysis while the definitions are listed in a table in the appendix. The wage gap and consumption expenditure gap have been estimated by using quantile regression technique. ${ }^{6}$ Quantile regression is a statistical technique that can be used to estimate and draw inference about the conditional quantile functions. The ordinary least square method results in estimates that approximate mean of dependent variable given certain values of the independent variables. Quantile regression on the other hand results in estimates that approximate either median or other quantiles of the dependent variable. It can be viewed as an extension of the classical linear regression estimation of conditional mean models.

6 This method can be used for estimating conditional quantile functions. In case of median regression number of positive and negative residuals that is, deviation of values from the median value is same. In case of other quantile regressions absolute deviations from the $\tau^{\text {th }}$ quantile will be asymmetric in nature. Different weights to positive and negative residuals will be attached in minimizing sum of absolute deviations from the $\tau^{\text {th }}$ quantile. Let $\mathrm{A}=(\mathrm{x} 1, \ldots, \mathrm{xn})$ denote the matrix consisting of $\mathrm{n}$ observed vectors of the random vector $\mathrm{X}$, and let $\mathrm{Y}=(\mathrm{y} 1, \ldots, \mathrm{yn})$ denote the $\mathrm{n}$ observed responses. The model for linear quantile regression is $Y=A^{\prime} \beta+u$, where $\theta=\left(\theta_{1}, \theta_{2}, \ldots, \theta_{k}\right)^{\prime}$ is the unknown k-dimensional vector of parameters, and $u=\left(u_{1}, u_{2}, \ldots ., u_{n}\right)^{\prime}$ is the $n$ dimensional vector of unknown disturbances. The $\tau^{\text {th }}$ quantile regression is the solution of the following problem: $\operatorname{Min}_{\beta} \sum_{i \in\left\{y_{i} \geq x_{i}^{\prime} \beta\right\}} \tau\left|y_{i}-x_{i}^{\prime} \beta\right|+\sum_{i \in\left\{y_{i}<x_{i}^{\prime} \beta\right\}}(1-\tau)\left|y_{i}-x_{i}^{\prime} \beta\right|$. STATA has been used for the quantile regression analysis following standard procedures. 
Hypothesis

The hypothesis we intend to test is the following. If the durable consumption expenditure is same for employees across public and private sector units in spite of a positive wage gap between the public and private sector in favour of the former, then it may imply presence of a positive level of non-reported earnings. We argue that it fits rather well with accounts of bribes accepted by public sector employees in India. We begin by estimating the private-public wage gap. The Quantile regression method is used for estimating the publicprivate wage gap at different percentiles of the conditional wage distribution.

The equation is given by,

$$
Q_{\theta}\left(\ln w_{i} \mid D_{-} \text {pub, } D_{-} \text {other }, X_{i}\right)=\alpha_{\theta}+\beta_{\theta} D_{-} p u b+\delta_{\theta} D_{-} \text {other }+\gamma_{\theta} X_{i}
$$

Here $w_{i}$ is the monthly wages and salary earned, $D_{-} p u b$ and $D_{-}$other are the enterprise dummies indicating the nature of enterprise $\left(D_{-} p u b=1\right.$ if an individual is employed in the public sector and 0 if he is employed in the private sector. On the other hand, $D_{-}$other $=1$ if the individual is employed in any sector other than the organised private and public sector). $X_{i}$ indicates the vector of individual-specific characteristics such as years of schooling, sex, experience, experience squared, five regional dummies, a sector dummy (rural versus urban), four dummies indicating whether the individual has a full time job, whether the job contract is for more than three years, whether he/she is eligible for paid leave and whether he/she receives social security benefits. $u_{i}$ is the random disturbance term.

The results are presented in Table 2. It indicates the presence of a positive and significant wage gap for the private sector over the public sector at the upper quantiles of wage distribution namely the $50^{\text {th }}$ quantile and $75^{\text {th }}$ quantile. However, the wage gap of 
private jobs over public sector jobs is negative and significant at the $25^{\text {th }}$ quantile. Public sector employees therefore earn higher wages than private sector employees for the low productive jobs but the wage gap reverses as one moves up the wage distribution. The results also show that the wage gap between public and private sector is highest among the most productive workers i.e. among the workers at the top quantile. The wage gap is $-.166 \log$ points at the $75^{\text {th }}$ quantile as compared to $-.0421 \log$-points at $50^{\text {th }}$ quantile and .054 logpoints at the $25^{\text {th }}$ quantile.

The results are consistent with the findings from the literature on wage gap in transition economies (viz. Adamchick and Bedi (2000), Brainerd (2002) \& Lokshin and Jovanovic (2003)). ${ }^{7}$ Earlier papers examining the wage gap using quantile regression technique have provided evidence for an upward sloping private-public wage gap. The wage loss among public-sector employees has usually been found to be the highest at the upper tail of wage distribution.

Therefore, it is possible that significant consumption gaps exist between public and private sector employees at the top quantiles. If the evidence suggests that the consumption gap is not significantly different from zero, it must be financed by source of income other than wage earnings. Lower wages of public sector employees may be offset by presence of nonpecuniary benefits namely availability of fringe benefits and presence of greater job security. Therefore, we have controlled for fringe benefits by including two dummies reflecting whether the person is eligible for paid leave and whether he receives social security benefits like pension so that the trade-off between present consumption and future consumption (present saving) is accounted for.

\footnotetext{
7 The result however is in contrast to the result for developed countries where the private-public wage gap is
} usually found to be negative and significant (Mueller 1998, Bender 2003, Melly 2005). 
Usually, public sector jobs provide more fringe benefits than private sector jobs and hence it is important to control for such benefits. Job security is controlled for by a dummy indicating whether one has a full-time job or not. Also our sample consists of regular salaried persons and hence the issue of job security is less of a concern. A much rigorous way of analyzing these issues is by looking at the quit rates of jobs. However, due to data limitations such an exercise could not be pursued here.

Information on consumption expenditure is available only at the household level. Hence the main analysis for this paper is done at the household level. The individual variables in equation 1 can be aggregated to the household level. The estimating equation for the household wage gap is given by $Q_{\theta}\left(\ln w_{h} \mid N_{h}^{\text {pub }}, N_{h}^{\text {other }}, N_{h}^{\text {earners }}, X_{h}\right)=\beta_{0 \theta}+\beta_{1 \theta} N_{h}^{\text {pub }}+\beta_{2 \theta} N_{h}^{\text {other }}+\beta_{3 \theta} N_{h}^{\text {earners }}+\gamma_{\theta} X_{h}^{\prime}$

Here $w_{h}$ is the wages and salaries earned by all the family members who worked as regular salaried/ wage employees; $N_{h}^{\text {pub }}$ denotes the number of household members employed in the public sector; $N_{h}^{\text {other }}$ denotes the number of household members employed in all the other sectors; and $N_{h}^{\text {earners }}$ is the number of wage earners in the household. $X_{h}$ includes the same variables as in equation 1 aggregated at the household level namely years of schooling, gender, experience, experience squared, full time job dummy, job contract dummy, paid leave eligibility dummy and social security dummy.

$X_{h}$ also includes regional dummies, sector dummy as well as household size. Focus will be on the coefficient of the variable of interest $N_{h}^{p u b} . \beta_{1}$ indicates the marginal change in 
household earnings when one more member is employed in the public sector instead of being employed in the private sector.

In order to examine whether there is a consumption gap across sectors the following equation has to be estimated.

$$
Q_{\theta}\left(\ln C_{h}^{\text {Dur }} \mid N_{h}^{\text {pub }}, N_{h}^{\text {other }}, N_{h}^{\text {earners }}, X_{h}\right)=\beta_{0 \theta}+\beta_{1 \theta} N_{h}^{\text {pub }}+\beta_{2 \theta} N_{h}^{\text {other }}+\beta_{3 \theta} N_{h}^{\text {earners }}+\gamma_{\theta} X_{h}^{\prime}
$$

The right hand side variables in the above equation are exactly the same as in the wage equation.

Results will be reported for wage and consumption expenditure gap for each of the three quantiles. namely the $25^{\text {th }}, 50^{\text {th }}$ quantile and the $75^{\text {th }}$ quantile. Results in Table 3 show that the marginal decrease in household wage earnings when one more member is employed in the public sector instead of being in the private sector is $0.128 \log$ points for the upper tail and that the effect is significant. However, for the lowest quantile namely the $25^{\text {th }}$ quantile, there is a significant increase in household wage earning by $0.064 \log$ points if one member switches from the public sector to the private sector and for the $50^{\text {th }}$ quantile there is no significant change in household earnings if there is a switch from private to public sector.

Table 4 on the other hand shows that for durable goods expenditure, the coefficient on $N_{h}^{\text {pub }}$ is insignificant for all the quantiles of consumption expenditure distribution. In other words there is no significant gap in durable good consumption expenditure across the two sectors for all the quantiles.

The results in our paper therefore lend support to our hypothesis that the most productive public sector employees receive income from other sources, which may be in the 
form of bribes. This should explain the positive wage gap between the private sector and public sector employees but without a significant gap in durable expenditure.

One may argue that job securities of the public sector employee are higher than that of private sector employee and as a result the marginal propensity to consume of private sector is lower than that of the public sector and thus there is no significant gap between the consumption expenditure of both the sectors. We tried to capture this aspect by controlling for paid leave eligibility dummy, social security dummy, full time dummy and job contract type dummy in our regression models. Again one can contradict our conclusions by pointing out that employees in different sectors with different levels of earnings may demonstrate same levels of consumption expenditure if private sector employees save more, pay higher taxes; conversely, public sector workers receive more transfers, such as subsidized housing, food supply, family pension, free schooling for children, etc. Due to paucity of such data, we will not be able to prove or disprove such claims. Nevertheless, the result at least hints at the possibility of such additional sources of income (or savings) flowing to a particular sector which is often ignored in India. Besides, we are looking at only one part of the total consumption expenditure namely expenditure on durable goods.

In order to strengthen our above claim, we also examined whether there is any gap in non-durable consumption expenditure between the two sectors. Results in Table 5 in the appendix show that there is a positive and significant gap in non-durable consumption expenditure between private sector and public sector for the uppermost quantile. Hence even though the family is earning more wage income and also spending more on nondurable goods if one more member gets employed in the private sector instead of being employed in the public sector, no such gap is observed in case of expenditure on durable goods. The 
unreported income is like the transitory income which is more likely to be spent on

different assets including durable goods and less likely to be spent on non-durable goods.This result therefore indicates that the public sector employees receive some non-reported earnings which enable them to spend on durable goods at comparable levels of employment categories vis-à-vis private-sector employees.

Table 1.1: Summary Statistics of Individual Wage Regression Variables

\begin{tabular}{|l|l|l|l|l|l|}
\hline Variable & Obs & Mean & Std. Dev. & Min & Max \\
\hline Region Dummy1 & 9786 & .1283466 & .3344924 & 0 & 1 \\
\hline Region Dummy2 & 9786 & .1733088 & .3785334 & 0 & 1 \\
\hline Region Dummy3 & 9786 & .3239321 & .4679984 & 0 & 1 \\
\hline Region Dummy4 & 9786 & .1431637 & .3502576 & 0 & 1 \\
\hline Region Dummy5 & 9786 & .2312487 & .4216526 & 0 & 1 \\
\hline Public Sector Dummy & 9786 & .6431637 & .4790904 & 0 & 1 \\
\hline Private Sector Dummy & 9786 & .2364602 & .4249297 & 0 & 1 \\
\hline Paid leave eligibility dummy & 9704 & .8572754 & .3498099 & 0 & 1 \\
\hline Social Security benefits Dummy & 9703 & .7880037 & .4087433 & 0 & 1 \\
\hline Full time Dummy & 9762 & .994161 & .0761936 & 0 & 1 \\
\hline Contract Dummy & 9786 & .5977928 & .4903684 & 0 & 1 \\
\hline Sex & 9786 & .7947067 & .4039364 & 0 & 1 \\
\hline Sector & 9786 & .6472512 & .4778498 & 0 & 1 \\
\hline Experience & 9581 & 16.55527 & 9.680297 & 0 & 39 \\
\hline Experience Square & 9581 & 367.7752 & 351.0911 & 0 & 1521 \\
\hline Years of Schooling & 9581 & 16.191 & 1.574472 & 15 & 21 \\
\hline Source Own calcutions & & & & & 0 \\
\hline
\end{tabular}

Source: Own calculations 
Table 1.2: Summary Statistics of Household Regression Variables

\begin{tabular}{|l|l|l|l|l|l|}
\hline Variable & Obs & Mean & Std. Dev. & Min & Max \\
\hline Region Dummy1 & 7327 & .1308858 & .3372984 & 0 & 1 \\
\hline Region Dummy2 & 7327 & .1669169 & .3729271 & 0 & 1 \\
\hline Region Dummy3 & 7327 & .3141804 & .4642203 & 0 & 1 \\
\hline Region Dummy4 & 7327 & .1504026 & .35749 & 0 & 1 \\
\hline Region Dummy5 & 7327 & .2374778 & .4255665 & 0 & 1 \\
\hline Public Sector Dummy & 7327 & .7664801 & .5942953 & 0 & 4 \\
\hline Private Sector Dummy & 7327 & .2871571 & .523515 & 0 & 3 \\
\hline Paid leave eligibility dummy & 7327 & 1.010782 & .5245994 & 0 & 5 \\
\hline Social Security benefits Dummy & 7327 & .9398117 & .543803 & 0 & 5 \\
\hline Full time Dummy & 7327 & 1.209636 & .4926431 & 0 & 5 \\
\hline Contract Dummy & 7327 & .719667 & .620009 & 0 & 4 \\
\hline Sex & 7327 & 1.049816 & .5212934 & 0 & 5 \\
\hline Sector & 7326 & .3340158 & .4716775 & 0 & 1 \\
\hline Experience & 7327 & 23.86052 & 15.30939 & 0 & 192 \\
\hline Experience Square & 7327 & 803.6697 & 1119.28 & 0 & 36864 \\
\hline Years of Schooling & 7327 & 24.58005 & 12.75917 & 15 & 127 \\
\hline Wages & 7327 & 11214.46 & 10610.91 & 88.2 & 538998.6 \\
\hline Durable Expenditure & 7325 & 446.9742 & 1509.743 & 0 & 49315.07 \\
\hline Non-Durable Expenditure & 7325 & 6040.029 & 3661.553 & 222 & 70782.88 \\
\hline Source: Own calcutions & & 0 & 0 \\
\hline
\end{tabular}

Source: Own calculations 
Table 2: Quantile Regressions: Individual Wage data $(\mathrm{N}=9487)$

\begin{tabular}{|c|c|c|c|}
\hline \multicolumn{4}{|c|}{ Dependent Variable: $\ln$ (wage) } \\
\hline Variables & $25^{\text {th }}$ Quantile & $50^{\text {th }}$ Quantile & $75^{\text {th }}$ Quantile \\
\hline D_Pub & $\begin{array}{l}.0542379 \quad * * \\
(.0238774)\end{array}$ & $\begin{array}{l}-.0421539 * * \\
(.0200757)\end{array}$ & $\begin{array}{l}-.1664174 * * * \\
(.0185044)\end{array}$ \\
\hline D_Oth & $\begin{array}{ll}-.2072256 & * * * \\
(.0260333) & \end{array}$ & $\begin{array}{l}-.2115648 * * * \\
.0222366\end{array}$ & $\begin{array}{l}-.3093612 * * * \\
(.0209574)\end{array}$ \\
\hline $\begin{array}{l}\text { Social Security } \\
\text { Dummy }\end{array}$ & $\begin{array}{l}.1602149 \quad * * * \\
(.0291533)\end{array}$ & $\begin{array}{l}.1558387 * * * \\
(.0237167)\end{array}$ & $\begin{array}{l}.1188728 * * * \\
(.0217429)\end{array}$ \\
\hline Paid Leave Dummy & $\begin{array}{ll}.8541781 & * * * \\
(.0275275) & \end{array}$ & $\begin{array}{l}.8081181 * * * \\
(.0220742)\end{array}$ & $\begin{array}{l}.6241039 * * * \\
(.020391)\end{array}$ \\
\hline Full time dummy & $\begin{array}{l}.4173002 * * * \\
(.0915375)\end{array}$ & $\begin{array}{l}.3263739 * * * \\
(.0789097)\end{array}$ & $\begin{array}{l}.2068489 * * * \\
(.0727106)\end{array}$ \\
\hline Contract Dummy & $\begin{array}{l}.0545813 * * * \\
(.0165465)\end{array}$ & $\begin{array}{l}.0517317 * * * \\
(.0140962)\end{array}$ & $\begin{array}{l}.0629574 * * * \\
(.0133135)\end{array}$ \\
\hline Experience & $\begin{array}{l}.0354923 * * * \\
(.0029029)\end{array}$ & $\begin{array}{l}.0286119 * * * \\
(.0024658)\end{array}$ & $\begin{array}{l}.0280473 * * * \\
(.0022817)\end{array}$ \\
\hline Experience square & $\begin{array}{l}-.0003342 * * * \\
(.0000774)\end{array}$ & $\begin{array}{l}-.0001929 * * * \\
(.0000658)\end{array}$ & $\begin{array}{l}-.000216^{* * *} \\
(.0000607)\end{array}$ \\
\hline Years of Schooling & $\begin{array}{l}.1007755^{* * *} \\
(.0046364)\end{array}$ & $\begin{array}{l}.1023139 * * * \\
(.0039575)\end{array}$ & $\begin{array}{l}.1093619 * * * \\
(.0036809)\end{array}$ \\
\hline Sex & $\begin{array}{l}.1413782 * * * \\
(.0179586)\end{array}$ & $\begin{array}{l}.1137203 * * * \\
(.0152492)\end{array}$ & $\begin{array}{l}.0876942 * * * \\
(.0142244)\end{array}$ \\
\hline Sector & $\begin{array}{l}.1406037 * * * \\
(.0154141) \\
\end{array}$ & $\begin{array}{l}.1756543 * * * \\
(.0129733)\end{array}$ & $\begin{array}{l}.1937528 * * * \\
(.0119776)\end{array}$ \\
\hline Region Dummy2 & $\begin{array}{l}.0775254 * * * \\
(.0271834)\end{array}$ & $\begin{array}{l}.0690893 * * * \\
(.0229678)\end{array}$ & $\begin{array}{l}.0266466 \\
(.0213781)\end{array}$ \\
\hline Region Dummy3 & $\begin{array}{l}.045906^{*} \\
(.0235303)\end{array}$ & $\begin{array}{l}.0847488 * * * \\
(.0199426)\end{array}$ & $\begin{array}{l}.0575627 * * * \\
(.0185471)\end{array}$ \\
\hline Region Dummy4 & $\begin{array}{l}.142203 * * * \\
(.0276792)\end{array}$ & $\begin{array}{l}.1475393 * * * \\
(.023451)\end{array}$ & $\begin{array}{l}.1103502 * * * \\
(.0217858)\end{array}$ \\
\hline Region Dummy5 & $\begin{array}{l}.046499 * \\
(.0250196) \\
\end{array}$ & $\begin{array}{l}.0251 \\
(.0211904)\end{array}$ & $\begin{array}{l}.0039045 \\
(.0197174)\end{array}$ \\
\hline
\end{tabular}


Pseudo R2

0.3891

0.3144

0.2614

Table 3: Quantile Regressions: Household Wage Data

$(\mathrm{N}=7326)$

\begin{tabular}{|c|c|c|c|}
\hline \multicolumn{4}{|c|}{ Dependent Variable: $\ln ($ wage) } \\
\hline Variables & $25^{\text {th }}$ Quantile & $50^{\text {th }}$ Quantile & $75^{\text {th }}$ Quantile \\
\hline$N_{h}^{p u b}$ & $\begin{array}{l}.0644225^{* * *} \\
(.0234425)\end{array}$ & $\begin{array}{l}.0176948 \\
(.0176817) \\
\end{array}$ & $\begin{array}{l}-.1284276^{* * *} \\
(.015952)\end{array}$ \\
\hline$N_{h}^{\text {other }}$ & $\begin{array}{l}-.1575357 * * * \\
(.0255302)\end{array}$ & $\begin{array}{l}.155791 * * * \\
(.019817)\end{array}$ & $\begin{array}{l}-.2241854 * * * \\
(.0185522)\end{array}$ \\
\hline$N_{h}^{E A R}$ & $\begin{array}{l}-.1632786^{* * * *} \\
(.0534487)\end{array}$ & $\begin{array}{l}.0363232 \\
(.0411992)\end{array}$ & $\begin{array}{l}.0680994 * * * \\
(.0342914)\end{array}$ \\
\hline Paid Leave Dummy & $\begin{array}{l}.1019284 * * * \\
(.0293674)\end{array}$ & $\begin{array}{l}.1149688^{* * *} \\
(.0219241)\end{array}$ & $\begin{array}{l}.1225508^{* * *} \\
(.0204906)\end{array}$ \\
\hline $\begin{array}{l}\text { Social Security } \\
\text { Dummy }\end{array}$ & $\begin{array}{l}.604087 * * * \\
(.0281403)\end{array}$ & $\begin{array}{l}.5312453 * * * \\
(.0207299)\end{array}$ & $\begin{array}{l}.4490891 * * * \\
(.0192812)\end{array}$ \\
\hline Contract Dummy & $\begin{array}{l}.072936^{* * *} \\
(.0162349)\end{array}$ & $\begin{array}{l}.0630237 * * * \\
(.0122937)\end{array}$ & $\begin{array}{l}.0520228 * * * \\
(.0112242)\end{array}$ \\
\hline Full time dummy & $\begin{array}{l}-.0129403 \\
(.047087) \\
\end{array}$ & $\begin{array}{l}-.042595 \\
(.0355734) \\
\end{array}$ & $\begin{array}{l}-.0367235^{* *} \\
(.0292828)\end{array}$ \\
\hline Experience & $\begin{array}{l}.0319739 * * * \\
(.0011665) \\
\end{array}$ & $\begin{array}{l}.028504 * * * \\
(.0010109) \\
\end{array}$ & $\begin{array}{l}.0239708 * * * \\
(.0011249) \\
\end{array}$ \\
\hline Experience square & $\begin{array}{l}-.0002929 * * * \\
(.0000142)\end{array}$ & $\begin{array}{l}-.0002399^{* * *} \\
(.0000135)\end{array}$ & $\begin{array}{l}-.0001822 * * * \\
(.0000166)\end{array}$ \\
\hline Years of Schooling & $\begin{array}{l}.0103778 * * * \\
(.0013404)\end{array}$ & $\begin{array}{l}.0093932 * * * \\
(.0009658)\end{array}$ & $\begin{array}{l}.0113438 * * * \\
(.0008427)\end{array}$ \\
\hline Sex & $\begin{array}{l}.1258398 * * * \\
(.0208457)\end{array}$ & $\begin{array}{l}.0993679 * * * \\
(.0153763)\end{array}$ & $\begin{array}{l}.1100173 * * * \\
(.0135882)\end{array}$ \\
\hline Household Size & $\begin{array}{l}-.0341268 * * * \\
(.0038988)\end{array}$ & $\begin{array}{l}-.0345194 * * * \\
(.0030457)\end{array}$ & $\begin{array}{l}-.032714 * * * \\
(.0029569)\end{array}$ \\
\hline Sector & $\begin{array}{l}-.0828538 * * * \\
(.0186745)\end{array}$ & $\begin{array}{l}-.101026 * * * \\
(.014229)\end{array}$ & $\begin{array}{l}-.1212631 * * * \\
(.0128334)\end{array}$ \\
\hline Region Dummy1 & $\begin{array}{l}-.1375678 * * * \\
(.0316253)\end{array}$ & $\begin{array}{l}-.1495281 * * * \\
(.0242401)\end{array}$ & $\begin{array}{l}-.1169147^{* * *} * \\
(.0220479)\end{array}$ \\
\hline Region Dummy2 & $\begin{array}{l}-.0796399 * * * \\
(.0309794)\end{array}$ & $\begin{array}{l}-.0999835^{* * *} \\
(.0235573)\end{array}$ & $\begin{array}{l}-.0688129 * * * \\
(.0212335)\end{array}$ \\
\hline Region Dummy3 & $\begin{array}{l}-.0487526 * * * \\
(.0264303)\end{array}$ & $\begin{array}{l}-.0379355^{*} \\
(.0202441) \\
\end{array}$ & $\begin{array}{l}-.0229813^{* * *} \\
(.0184869)\end{array}$ \\
\hline Region Dummy5 & $\begin{array}{l}-.1113183 * * * \\
(.0272309)\end{array}$ & $\begin{array}{l}-.1383711 * * * * \\
(.0209327)\end{array}$ & $\begin{array}{l}-.0751881 * * * \\
(.0191387)\end{array}$ \\
\hline Pseudo R2 & 0.3341 & 0.2937 & 0.2779 \\
\hline
\end{tabular}


Table 4: Quantile Regressions: Household Durable Consumption Expenditures (N=6268)

\begin{tabular}{|c|c|c|c|}
\hline \multicolumn{4}{|c|}{ Dependent Variable: $\ln$ (Durable Expenditure) } \\
\hline Variables & $25^{\text {th }}$ Quantile & $50^{\text {th }}$ Quantile & $75^{\text {th }}$ Quantile \\
\hline$N_{h}^{p u b}$ & $\begin{array}{l}-.0532548 \\
(.0716371)\end{array}$ & $\begin{array}{l}-.077596 \\
(.0827866)\end{array}$ & $\begin{array}{l}-.0165635 \\
(.0731715)\end{array}$ \\
\hline$N_{h}^{\text {other }}$ & $\begin{array}{l}-.1967293 * * \\
(.0803631)\end{array}$ & $\begin{array}{l}-.2014868 * * \\
(.093399)\end{array}$ & $\begin{array}{c}-.0498366 \\
(.0832384)\end{array}$ \\
\hline$N_{h}^{E A R}$ & $\begin{array}{l}-.099498 \\
(.174397)\end{array}$ & $\begin{array}{l}-.0739099 \\
(.1894299)\end{array}$ & $\begin{array}{l}-.2313868 \\
(.1588009)\end{array}$ \\
\hline Paid Leave Dummy & $\begin{array}{l}.1833261^{* *} \\
(.090064)\end{array}$ & $\begin{array}{l}.2617349 * * \\
(.1036147)\end{array}$ & $\begin{array}{l}.1612415^{*} \\
(.0939835)\end{array}$ \\
\hline $\begin{array}{l}\text { Social Security } \\
\text { Dummy }\end{array}$ & $\begin{array}{l}.2179805^{* *} \\
(.085563)\end{array}$ & $\begin{array}{l}.1258145 \\
(.0966729)\end{array}$ & $\begin{array}{l}.3307004 * * * \\
(.0896199)\end{array}$ \\
\hline Contract Dummy & $\begin{array}{l}.0467114 \\
(.0497574)\end{array}$ & $\begin{array}{l}.0959161 * \\
(.0575264)\end{array}$ & $\begin{array}{l}.0488393 \\
(.0511877)\end{array}$ \\
\hline Full time dummy & $\begin{array}{l}-.1032357 \\
(.152)\end{array}$ & $\begin{array}{l}-.0477404 \\
(.1644848)\end{array}$ & $\begin{array}{l}.0228376 \\
(.1356919)\end{array}$ \\
\hline Experience & $\begin{array}{l}.0231109 * * * \\
(.0038023)\end{array}$ & $\begin{array}{l}.0198184 * * * \\
(.0047088)\end{array}$ & $\begin{array}{l}.0116742 * * * \\
(.0036456)\end{array}$ \\
\hline Experience square & $\begin{array}{l}-.0002153 * * * \\
(.0000477)\end{array}$ & $\begin{array}{l}-.0001543 * * \\
(.0000611)\end{array}$ & $\begin{array}{l}-.0001029 * * * \\
(.0000389)\end{array}$ \\
\hline Years of Schooling & $\begin{array}{l}.0067708^{*} \\
(.003955)\end{array}$ & $\begin{array}{l}.0069328 \\
(.0045377)\end{array}$ & $\begin{array}{l}.0067987 \\
(.0039726)\end{array}$ \\
\hline Sex & $\begin{array}{l}-.1260495^{*} \\
(.0647888)\end{array}$ & $\begin{array}{l}-.1665087 * * \\
(.0737043)\end{array}$ & $\begin{array}{l}-.2587296 * * * \\
(.0654355)\end{array}$ \\
\hline Household Size & $\begin{array}{l}.0923638 \\
(.0129193)\end{array}$ & $\begin{array}{l}.073976 * * * \\
(.0146187)\end{array}$ & $\begin{array}{l}.0433914 * * * \\
(.0123578)\end{array}$ \\
\hline Sector & $\begin{array}{l}.0470029 \\
(.0577628)\end{array}$ & $\begin{array}{l}-.0228238 \\
(.0671391)\end{array}$ & $\begin{array}{l}-.0787942 \\
(.0606175)\end{array}$ \\
\hline Region Dummy1 & $\begin{array}{l}-.6386988 * * * \\
(.096071)\end{array}$ & $\begin{array}{l}-.5755636 * * * \\
(.1119495)\end{array}$ & $\begin{array}{l}-.5095627^{* * * *} \\
(.099416)\end{array}$ \\
\hline Region Dummy2 & $\begin{array}{l}.1239593 \\
(.0966134)\end{array}$ & $\begin{array}{l}-.0598486 \\
(.1111615)\end{array}$ & $\begin{array}{l}-.1384487 \\
(.0990128)\end{array}$ \\
\hline Region Dummy3 & $\begin{array}{l}-.0392482 \\
(.0808106)\end{array}$ & $\begin{array}{l}-.1219745 \\
(.0939966)\end{array}$ & $\begin{array}{l}-.1717091^{* *} \\
(.08392)\end{array}$ \\
\hline Region Dummy5 & $\begin{array}{l}-.2608679 * * * \\
(.0862638)\end{array}$ & $\begin{array}{l}-.240518 * * \\
(.1007189)\end{array}$ & $\begin{array}{l}-.0158909 \\
(.0899431)\end{array}$ \\
\hline Pseudo R2 & 0.0582 & 0.0515 & 0.0403 \\
\hline
\end{tabular}




\section{A Theoretical Model}

The empirical result motivates us to offer a theoretical estimate of bribe or unaccounted for income earned by public sector workers. The dual labor market characteristic of a developing country is an important specification in this structure. The comparative static changes allow for labor adjustments in the large informal sector. The informal sector is defined as a low wage, high employment sector present in most developing and transition countries. It tends to accommodate a large number of workers at market clearing wages. Details on informal economics is available in Agenor and Montiel (1997), Carruth and Oswald (1981), Marjit (2003), etc.

Consider a risk-neutral individual who maximizes an additive utility function $U^{j}=U\left(C_{j D}, C_{j N}\right), U^{\prime}>0, U^{\prime \prime}<0, j=G, \operatorname{Pr}$, subject to a budget constraint, $\sum_{i} P_{i} C_{j i}=M_{j}$ and $i=D, N$. ' $D$ ' stands for durable goods and ' $N$ ' stands for non-durable goods; ' $G$ ' stands for public sector and ' $\mathrm{Pr}$ ' denotes private sector; $\left(C_{j D}, C_{j N}\right)$ are consumptions of durable and non-durable goods by sector types. ${ }^{8}$ The individual has two choices with regard to labor force participation - work in the public sector at a given wage $w_{G}$ or in the private sector (at a comparable position) offering an efficiency wage $w_{\operatorname{Pr}}>w_{G}$. In case, a worker does not find employment in any of these (formal) sectors he joins the informal sector for a market-clearing wage $w_{I} \cdot{ }^{9}$

Let us assume that the labor force is homogeneous and ( $w_{\mathrm{Pr}}$ and $\left.w_{G}\right)$ are given.

\footnotetext{
${ }^{8}$ It should be noted that this problem with 'pure consumption' in theoretical models vis-à-vis 'consumption expenditure' in empirical analyses is discussed in several places, including Seater and Mariano (1985).

${ }^{9}$ We bypass formal wage determination here, since it has been dealt with at great length in previous studies. See for example, Cahuc and Zylberberg (2004). Marjit (2003) discusses determination of informal wage. It also discusses the distribution of workforce between formal and informal sectors in a typical developing country.
} 
However, presence of efficiency and minimum wages leads to fewer jobs in the formal sector. A large number of workers settle for a fairly low wage in the informal sector. The wage determination leads to $w_{\operatorname{Pr}}>w_{G}>w_{I}$.

Thus, the utility function for workers joining the public sector is given by:

$$
U^{G}\left(C_{G D}, C_{G N}\right)=\ln C_{G D}^{\alpha} C_{G N}^{1-\alpha}
$$

where, $C_{G D}^{\alpha}$ is the consumption of 'durable' goods by those working in the public sector $C_{G N}^{1-\alpha}$ is the consumption of 'Non-Durable' goods by those working in the public sector; $0<\alpha<1$ is the propensity to consume $D$ (consumer preferences are identical and homogeneous within each quantile). $\lambda^{G}$ is the marginal utility of income for those in the public sector. Let $q$ be the probability that a public sector worker accepts bribe without getting apprehended; $1-q$ is the probability that he is caught and fired. ${ }^{10}$ In that case, the retrenched worker joins the informal sector and earns $w_{I}, \beta$ is the percentage of wage that comes as social security benefits to public sector workers. Finally, $B$ represents all 'unreported' income including bribes. Thus, for the public sector workers income earned is:

$$
M_{G}=q\left[w_{G}(1+\beta)+B\right]+(1-q) w_{I}
$$

On the other hand, for employees in the private sector,

$$
U^{\operatorname{Pr}}\left(C_{\operatorname{Pr} D}, C_{\operatorname{Pr} N}\right)=\ln C_{\operatorname{Pr} D}^{\alpha} C_{\operatorname{Pr} N}^{1-\alpha}
$$

is the direct utility attained by workers in the private sector maximized subject to the budget constraint:

10 Bribes accepted in cash or kind, tax evasion, etc. may cause suspension at the work place and subsequently job loss. Other forms of unreported income earned from undocumented property or business may also lead to suspension and job loss from public sector units if the person is apprehended or arrested on such grounds by other enforcement authorities. 


$$
M_{\mathrm{Pr}}=k\left[w_{\mathrm{Pr}}+T\right]+(1-k) w_{I}
$$

For private sector workers, $k$ stands for exogenous probability of job losses in the private sector; and $T$ is lump-sum transfer/fringe benefits received by private sector employees; (1-k) is the exogenous probability of losing jobs and joining the informal sector.

Without using the tools of standard maximization exercise it can be shown from these specifications that due to identical preferences the comparison will essentially be one between the constraints faced by each group. Nevertheless, the maximization problem (viz. for public sector) may be written as:

$$
\Lambda^{G}=\ln C_{G D}^{\alpha} C_{G N}^{1-\alpha}+\lambda^{G}\left\{q\left[w_{G}(1+\beta)+B\right]+(1-q) w_{I}-P_{D} C_{G D}-P_{N} C_{G N}\right\}
$$

The first order conditions solve for $\left(C_{G D}^{*}, C_{G N}^{*}\right)$ :

$$
\begin{aligned}
& C_{G D}^{*}=\frac{\alpha}{P_{D}}\left[q\left\{w_{G}(1+\beta)+(1-q) w_{I}\right]\right. \\
& \text { and, } C_{G N}^{*}=\frac{1-\alpha}{P_{N}}\left[q\left\{w_{G}(1+\beta)+(1-q) w_{I}\right]\right.
\end{aligned}
$$

Similarly, for the employees of the private sector consumption levels are given by:

$$
\begin{aligned}
& C_{\operatorname{Pr} D}^{*}=\frac{\alpha}{P_{D}}\left[k\left(w_{\operatorname{Pr}}+T\right)+(1-k) w_{I}\right] \\
& C_{\operatorname{Pr} N}^{*}=\frac{1-\alpha}{P_{N}}\left[k\left(w_{\operatorname{Pr}}+T\right)+(1-k) w_{I}\right]
\end{aligned}
$$

Note that, our empirical findings suggest higher wage for private sector employees at the higher quantiles, and a consumption gap in terms of non-durable goods. The consumption of durable goods even at the highest quantile is however same across public and private sector employees. This suggests, 


$$
C_{G D}^{*}=C_{\operatorname{Pr} D}^{*} \text { while } C_{G N}^{*}<C_{\operatorname{Pr} N}^{*}
$$

Since $C_{G N}^{*}<C_{\operatorname{Pr} N}^{*}$ is expected and commensurate with empirical findings, it does not offer a measure of the unreported income. But $C_{G D}^{*}=C_{\operatorname{Pr} D}^{*}$, as we have argued earlier, suggests that the consumption of durable goods is equal across public and private sector workers and may have been financed by unreported income flowing to public sector employees. Therefore comparing (9) and (11) we get a level of such unreported income.

$$
\begin{aligned}
& q\left[w_{G}(1+\beta)+B\right]+(1-q) w_{I}=k\left(w_{\mathrm{Pr}}+T\right)+(1-k) w_{I} \\
& \text { or, } \quad B^{*}=\left[\frac{k}{q}\left(w_{\mathrm{Pr}}+T\right)-w_{G}(1+\beta)\right]+\left(1-\frac{k}{q}\right) w_{I}
\end{aligned}
$$

Expression (14) offers the level of unreported income flowing to public sector employees that helps to equate consumption levels (of durable goods) across public and private sector jobs. If the public and private sector workers take $W_{I}$ as given (we relax this assumption later), then the amount of bribes accepted goes up as the informal wage goes up (if, $q>k$ ). Similarly, higher is the private sector wage, higher is the bribe accepted, while it varies inversely with the public sector wage. Apart from the modeling specifications (bribes treated as compensating differential) that drive these results, it should also be readily interpretable intuitively. If consumption of durable goods and assets (like accommodation, household equipments, jewelry, etc) need to be quite similar at comparable occupational classifications across public and private sector, but wage incomes do not match, the usual recourse is unreported income. However, acceptance of bribes is subject to penalty that drives workers to the catchall informal sector. Thus, if the informal sector (for purely exogenous reasons) do offer a high wage then the threat of job loss due to acceptance of bribes would be low and 
consequently, the level of bribes should go up in equilibrium. An increase in the probability of apprehension also lowers equilibrium bribe unambiguously;

$$
\frac{\delta B^{*}}{\delta q}=\frac{k}{q^{2}}\left[w_{I}-\left(w_{\mathrm{Pr}}+T\right)\right]<0 .
$$

Interestingly, a comparison of (10) and (12) also offers an upper bound on how much the unreported income could be if the private sector workers consume more non-durable goods than the public sector workers. It is given by,

$$
B^{*}<\left[\frac{k}{q}\left(w_{\operatorname{Pr}}+T\right)-w_{G}(1+\beta)\right]+\left(1-\frac{k}{q}\right) w_{I}
$$

Result 1: $\quad$ Public sector workers consume as much durable goods as the employees in the private sector at a level of unreported income $B^{*}$ as in (14). The level of $B^{*}$ responds positively to a change in private sector income and negatively to that in the public sector; it also responds positively to a change in exogenous informal wage if probability of job loss in the private sector is lower than that in the public sector.

Proof: As discussed above.

Finally, we relax the assumption on exogenous informal wage. We model wage determination in the informal sector in the following way. Let $L$ be total employment in the formal sector. Then out of a total labor force $(\bar{L}),(\bar{L}-L)$ works in the informal sector. Homogeneity of labor force allows free mobility between formal and informal sectors. According to our specifications, there is a continuous entry into the informal sector by $(1-q+k) L$. This outflow from the formal sector includes probability of losing jobs from the public sector and private sector. Thus the rate of 'job acquisition' into the formal sector is 
the demand for 'formal' labor in the economy. One may find a similar treatment in Shapiro-Stiglitz (1984) where loss of formal jobs leads to unemployment with (a minimum) unemployment benefit. There is possibility of reentry into the employment pool given the rate of job creation. Unemployment benefits works poorly in most developing countries. The informal sector on the other hand, is quite dynamic and adjusts to labor inflows and outflows spontaneously. Thus, we redefine ‘job acquisition’ a la Shapiro-Stiglitz (1984) as the outflow from and inflow into the informal sector. These must be equal and defined as ' $a$ '.

$$
(1-q+k) L=a(\bar{L}-L)
$$

or, $\quad \frac{(1-q+k) L}{(\bar{L}-L)}=a$

Let the informal wage be, $w_{I}=\exp (a)$

Such that, $w_{I}^{\prime}>0, w_{I}^{\prime \prime}>0$. Note that, $\lim _{L \rightarrow 0} w_{I}=1$, while, $\lim _{L \rightarrow \bar{L}} w_{I}=\infty$. The relationship suggests that higher is ' $a$ ', i.e., as more workers get jobs in the formal sector the marginal productivity of labor rises in the informal sector and raises wage there. The opposite happens if ' $a$ ' is low due to greater entry into and lower exit from the informal sector. Using (16), (17) and substituting in (14):

$$
B^{*}=\left[\frac{k}{q}\left(w_{\operatorname{Pr}}+T\right)-w_{G}(1+\beta)\right]+\left(1-\frac{k}{q}\right) \exp \left[\frac{(1-q+k) L}{\bar{L}-L}\right]
$$

Note that, as the informal wage in now a function of $k$ and $q$

$$
\frac{\delta B^{*}}{\delta q}=\frac{k}{q^{2}}\left[\frac{\bar{L}-L+q L}{\bar{L}-L} \exp \frac{(1-q+k) L}{\bar{L}-L}-\left(w_{\mathrm{Pr}}+T\right)\right] \underset{<}{<} 0
$$

Similarly, a rise in $k$ will have opposing effects: the private sector wage and transfers compared to the effect of a change in $k$ on informal wage. If the given private sector wage 
and transfer continues to be higher than the effect of $k$ on the informal wage, equilibrium bribe must rise with a rise in $k$.

\section{Concluding Remarks}

Corruption among the public sector workers is very high in many countries. Recently, a number of studies have come up which document the level of corruption. One important finding of this literature is that bribes support consumption of durable and non-durable goods. In fact, the evidence from some of the countries, like Ukraine show that the consumption gap between the low- income public sector workers and the high-income private sector workers is bridged by positive amounts of bribes. In the current paper, we start with a similar premise that everything else remaining constant, if there is a positive wage gap between private and public sector in favour of the former, then consumption levels for private sector workers should also be higher than their public sector counterparts. If that is not true, then the consumption expenditure parity hints at the possibility of some unreported income accruing to the public sector employees. We test this hypothesis for India using the NSSO data for the year 2004-05 and by applying a quantile regression method. The empirical results show that at upper quantiles of income distribution, the private sector workers earn more than the public sector workers . However expenditure on durable goods is not statistically different between these two groups of workers. ${ }^{11}$ This therefore hints at the presence of unreported income earned by public sector employees.

The empirical section is followed by a brief theoretical exercise. The theoretical model

11 Private sector employees spend more on non-durable goods though. Expenditure on non-durable goods accounts for the daily necessities. The unreported income is like a transitory income which is spent on different types of assets including durable goods. Hence durable consumption expenditure parity hints at the presence of such unreported income. 
offers a measure of the equilibrium amount of bribe when the public sector workers and the private sector workers decide to self-select themselves into these sectors under different conditions of employment. In addition to the public and private sector, there is a third sector called the informal sector, where free labor mobility determines the market-clearing wage. The outside opportunity replaces unemployment benefit in more celebrated models. The theoretical model comes up with a measure of an equilibrium level of bribes that help to cover the consumption gap between these workers and the private sector employees.

It is worth mentioning that our empirical results are in accordance with our hypothesis only for the uppermost quantile and not for the other quantiles. The results, therefore, do not strictly support the hypothesis that public sector employees receive large amount of bribes and spend the same on durable consumption. In fact, the lack of evidence might be strongly indicative of the presence of large amount of black money in the system, which are hoarded or invested in clandestine activities and instruments. This requires further empirical investigation beyond the scope of the current study.

\section{References}

Adamchik, Vera A., Bedi, Arjun S., 2000.Wage differentials between the public and the private sectors: evidence from an economy in transition. Labour Economics 7, 203-224.

Agenor, R. and P. Montiel (1997), Development Macroeconomics, $2^{\text {nd }}$ edition, NJ: Princeton University Press.

Bender, Keith A., 2003. Examining equality between public and private sector wage distributions. Economic Inquiry 41, 62-79.

Brainerd, Elizabeth, 2002. Five years after: the impact of mass privatization on wages in 
Russia, 1993-1998. Journal of Comparative Economics 30, 160-190.

Carruth, A. and A. J. Oswald (1981), The Determination of Union and Non-union Wage Rates, European Economic Review, 16, 2/3, pp. 285-302.

Chaudhuri, Kausik, Schneider, Friedrich and Chattopadhyay, Sumana (2006), The size and development of the shadow economy: An empirical investigation from states of India, Journal of Development Economics, 80, 2, 428 - 443

Glinskaya, Elena and Lokshin, Michael (2007), Wage differentials between the public and private sectors in India, Journal of International Development, 19, 3, 333-355.

Gorodnichenko, Yuriy, Sabirianova Peter, Klara, 2007. Public Sector Pay and Corruption: Measuring Bribery from Micro Data. Journal of Public Economics, 91, 963-991.

Gupta, S, Davoodi, H and Alonso-Terme, R (2002), Does Corruption Affect Income Inequality and Poverty? Economics of Governance, 3, 1, 23-45.

Hillman, A.L., Krausz, M., 2004. Development failure, corruption, and the financial system. Paper presented at the European Public Choice Society Conference in Berlin, April 15-18.

Johnson, Simon, Kaufman, Daniel, McMillan, John, Woodruff, Christopher, 2000. Why do firms hide? Bribes and unofficial economy after communism. Journal of Public Economics $76,495-520$.

Lokshin, Michael M., Jovanovic, Branko, 2003. Wage differentials and state private sector employment choice in Yugoslavia. Economics of Transition 11, 463-491.

Marjit, S. (2003): Economic reform and Informal wage - A General Equilibrium Analysis, Journal of Development Economics, 72, 1, pp 371-378.

Melly, Blaise, 2005. Public-private sector wage differentials in Germany: evidence from quantile regression. Empirical Economics 30, 505-520. 
Mocan, Naci (2004), What determines corruption? International evidence from micro data. NBER Working Paper, No. 10460.

Mueller, Richard E., 1998. Public-private sector wage differentials in Canada: evidence from quantile regressions. Economics Letters 60, 229-235.

Saha, Bibhas (2001), Red Tape, incentive bribe and provision of subsidy, Journal of Development Economics, 65, 113 - 133.

Seater, J and Mariano, R (1985), New tests of the life-cycle and tax discounting hypotheses, Journal of Monetary Economics, 15, 195-215.

Singh, Gurbachan (2008), Financial Repression, Bank Deposits, Real Assets and Black Money, Discussion Paper No. 09-05, CITD, Jawaharlal Nehru University, New Delhi.

Tanzi, Vito and H. Davoodi (1997), Corruption, Public Investment and Growth, IMF Working Paper No. 97/139

Tzannatos, Z and S Roddis (1998), Unemployment Benefits, Social protection Discussion Paper series \# 9813, Social protection Unit, World Bank, Washington DC.

van Rijckeghem, Caroline, Weder, Beatrice (2001), Bureaucratic corruption and the rate of temptation: do wages in the civil service affect corruption, and by how much? Journal of Development Economics 65, 307-331. 


\section{Appendix}

Table 5: Quantile Regressions: Household Non-Durable Consumption Expenditures(N=6268)

\begin{tabular}{|c|c|c|c|}
\hline \multicolumn{4}{|c|}{ Dependent Variable: $\ln$ ( non-Durable Expenditure) } \\
\hline Variables & $25^{\text {th }}$ Quantile & $50^{\text {th }}$ Quantile & $75^{\text {th }}$ Quantile \\
\hline$N_{h}^{p u b}$ & $\begin{array}{l}-.0844345 * * * \\
(.0198734)\end{array}$ & $\begin{array}{l}-.0759297 * * * \\
(.018182)\end{array}$ & $\begin{array}{l}-.1056396^{* * *} \\
(.0209296)\end{array}$ \\
\hline$N_{h}^{\text {other }}$ & $\begin{array}{l}-.0910613 * * * \\
(.0225146)\end{array}$ & $\begin{array}{l}-.0818564 * * * \\
(.0203935)\end{array}$ & $\begin{array}{l}-.1061486^{* * *} \\
(.0236045)\end{array}$ \\
\hline$N_{h}^{E A R}$ & $\begin{array}{l}.0164392 \\
(.0465114)\end{array}$ & $\begin{array}{l}.0522573 \\
(.0422861)\end{array}$ & $\begin{array}{l}.1197419 * * * \\
(.0450428)\end{array}$ \\
\hline Paid Leave Dummy & $\begin{array}{l}.0696573 * * * \\
(.0247349)\end{array}$ & $\begin{array}{l}.0801728 * * * \\
(.0224933)\end{array}$ & $\begin{array}{l}.0483036^{*} \\
(.0260907)\end{array}$ \\
\hline $\begin{array}{l}\text { Social Security } \\
\text { Dummy }\end{array}$ & $\begin{array}{l}.1729917 * * * \\
(.0238122)\end{array}$ & $\begin{array}{l}.1404456^{* * *} \\
(.0212514)\end{array}$ & $\begin{array}{l}.1321284 * * * \\
(.0246174)\end{array}$ \\
\hline Contract Dummy & $\begin{array}{l}.0010538 \\
(.0139153)\end{array}$ & $\begin{array}{l}-.0036102 \\
(.0126128)\end{array}$ & $\begin{array}{l}.0117004 \\
(.0146353)\end{array}$ \\
\hline Full time dummy & $\begin{array}{l}-.0752635^{*} \\
(.03963)\end{array}$ & $\begin{array}{l}-.1010059^{* * *} \\
(.036625)\end{array}$ & $\begin{array}{l}-.1569152 * * * \\
(.0382968)\end{array}$ \\
\hline Experience & $\begin{array}{l}.0143284 * * * \\
(.0010676)\end{array}$ & $\begin{array}{l}.0124325^{* * *} \\
(.0010379)\end{array}$ & $\begin{array}{l}.0106109 * * * \\
(.0010416)\end{array}$ \\
\hline Experience square & $\begin{array}{l}-.0001287 * * * \\
(.0000139)\end{array}$ & $\begin{array}{l}-.0001006^{* * *} \\
(.0000139)\end{array}$ & $\begin{array}{l}-.000067 * * * \\
(.0000113)\end{array}$ \\
\hline Years of Schooling & $.0017594(.001088)$ & $\begin{array}{l}.0028466^{* * *} \\
(.0009915) \\
\end{array}$ & $\begin{array}{l}.0044177 * * * \\
(.0011331)\end{array}$ \\
\hline Sex & $\begin{array}{l}.1080077 * * * \\
(.0173667)\end{array}$ & $\begin{array}{l}.0892675 * * * \\
(.0158057)\end{array}$ & $\begin{array}{l}.0905834 * * * \\
(.0181847)\end{array}$ \\
\hline Household Size & $\begin{array}{l}.0924201 * * * \\
(.0039198)\end{array}$ & $\begin{array}{l}.0838341 * * * \\
(.0031344) \\
\end{array}$ & $\begin{array}{l}.0784051 * * * \\
(.0032562)\end{array}$ \\
\hline Sector & $\begin{array}{l}-.2966369 * * * \\
(.0160962)\end{array}$ & $\begin{array}{l}-.3281677^{* * *} \\
(.0146133)\end{array}$ & $\begin{array}{l}-.317078 * * * \\
(.0168477)\end{array}$ \\
\hline Region Dummy2 & $\begin{array}{l}.1082241 * * * \\
(.0264628)\end{array}$ & $\begin{array}{l}.1038327 * * * \\
(.0243317)\end{array}$ & $\begin{array}{l}.1368221 * * * \\
(.0282351)\end{array}$ \\
\hline Region Dummy3 & $\begin{array}{l}.1363927 * * * \\
(.0232723)\end{array}$ & $\begin{array}{l}.1342364 * * * \\
(.0214037)\end{array}$ & $\begin{array}{l}.1542765 * * * \\
(.0247549) \\
\end{array}$ \\
\hline Region Dummy4 & $\begin{array}{l}.2181826^{* * *} \\
(.0271524)\end{array}$ & $\begin{array}{l}.1815544 * * * \\
(.0249195)\end{array}$ & $\begin{array}{l}.142468 * * * \\
(.0286712)\end{array}$ \\
\hline Region Dummy5 & $\begin{array}{l}.1893048^{* * *} \\
(.0246136)\end{array}$ & $\begin{array}{l}.1627628 * * * \\
(.0226676)\end{array}$ & $\begin{array}{l}.1778851 * * * \\
(.0262347)\end{array}$ \\
\hline Pseudo R2 & 0.2314 & 0.2133 & 0.1854 \\
\hline
\end{tabular}


Table 6: Definition of Variables

\begin{tabular}{|c|c|c|c|}
\hline $\begin{array}{l}\text { Name of the } \\
\text { Variable in the } \\
\text { Survey }\end{array}$ & Survey Code & $\begin{array}{l}\text { Name of the } \\
\text { Variable in Paper }\end{array}$ & Method of Calculation \\
\hline $\begin{array}{l}\text { educational } \\
\text { level - general } \\
\text { (v1) }\end{array}$ & $\begin{array}{l}\text { not literate }-01 \text {, literate without } \\
\text { formal schooling: EGS/ NFEC/ } \\
\text { AEC -02, TLC }-03 \text {, others }-04 \text {; } \\
\text { literate: below primary }-05 \text {, primary } \\
-06 \text {, middle }-07 \text {, secondary }-08 \text {, } \\
\text { higher secondary }-10 \text {, } \\
\text { diploma/certificate course }-11 \text {, } \\
\text { graduate -12, postgraduate and } \\
\text { above }-13\end{array}$ & $\begin{array}{l}\text { Years of } \\
\text { Schooling } \\
\text { (general) }\end{array}$ & $\begin{array}{l}=0 \text { if } \mathrm{v} 1=1,2,3,4 \\
=4 \text { if } \mathrm{v} 1=5 \\
=5 \text { if } \mathrm{v} 1=6 \\
=9 \text { if } \mathrm{v} 1=7 \\
=10 \text { if } \mathrm{v} 1=8 \\
=12 \text { if } \mathrm{v} 1=10 \\
=13 \text { if } \mathrm{v} 1=11 \\
=15 \text { if } \mathrm{v} 1=12 \\
=17 \text { if } \mathrm{v} 1=13\end{array}$ \\
\hline \multirow[t]{2}{*}{$\begin{array}{l}\text { educational } \\
\text { level - technical } \\
\text { (v2) }\end{array}$} & \multirow[t]{2}{*}{$\begin{array}{l}\text { no technical education }-01 \text {, } \\
\text { technical degree in agriculture/ } \\
\text { engineering/ technology/ medicine, } \\
\text { etc. -02, diploma or certificate } \\
\text { (below graduate level) in: } \\
\text { agriculture -03, engineering/ } \\
\text { technology -04, medicine }-05 \text {, } \\
\text { crafts -06, other subjects }-07 \text {; } \\
\text { diploma or certificate (graduate and } \\
\text { above level) in: agriculture }-08 \text {, } \\
\text { engineering/ technology }-09 \text {, } \\
\text { medicine -10, crafts }-11, \quad \text { other } \\
\text { subjects }-12\end{array}$} & $\begin{array}{l}\text { Years } \\
\text { Schooling } \\
\text { (technical) }\end{array}$ & 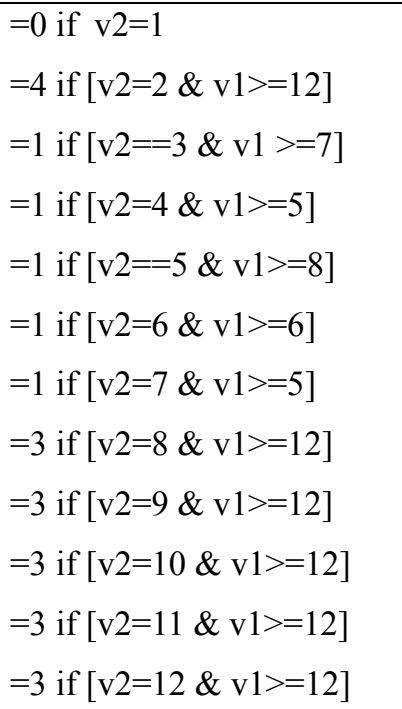 \\
\hline & & $\begin{array}{l}\text { Years } \\
\text { Schooling }\end{array}$ & $\begin{array}{l}\text { Years of Schooling } \\
\text { (general) } \\
\text { Years of Schooling } \\
\text { (technical) }\end{array}$ \\
\hline \multirow[t]{3}{*}{ Age } & \multirow[t]{3}{*}{ years } & Age & years \\
\hline & & Experience & $=$ age-years of schooling -6 \\
\hline & & $\begin{array}{l}\text { Experience } \\
\text { square }\end{array}$ & $=$ Experience $*$ Experience \\
\hline Sex & Male- 1 & Sex & $=1$ if male \\
\hline
\end{tabular}




\begin{tabular}{|c|c|c|c|}
\hline & Female - 2 & & $=0$ if female \\
\hline \multirow[t]{2}{*}{ Enterprise Type } & \multirow[t]{2}{*}{$\begin{array}{l}\text { Government/public sector }-5, \\
\text { Public/Private limited company }-6\end{array}$} & $\begin{array}{l}\text { Public sector } \\
\text { Employee } \\
\text { (D_Pub) }\end{array}$ & $\begin{array}{l}=1 \text { if enterprise type }=6 \\
=0 \text { if employed in the } \\
\text { private sector }\end{array}$ \\
\hline & & $\begin{array}{l}\text { Others sector } \\
\text { Employee } \\
\text { (D_oth) }\end{array}$ & $\begin{array}{l}=1 \text { if not employed in the } \\
\text { organized public and } \\
\text { private sector } \\
=0 \text { if employed in the } \\
\text { private sector }\end{array}$ \\
\hline $\begin{array}{l}\text { availability of } \\
\text { social security } \\
\text { benefits }\end{array}$ & $\begin{array}{l}\text { eligible for: only PF/ pension (i.e., } \\
\text { GPF, CPF, PPF, pension, etc.) } \\
\text {-1,only gratuity } 2 \text {, only health care } \\
\text { \& maternity benefits }-3 \text {, only PF/ } \\
\text { pension and gratuity }-4 \text {, only PF/ } \\
\text { pension and health care \& } \\
\text { maternity benefits }-5 \text { only gratuity } \\
\text { and health care \& maternity } \\
\text { benefits }-6, \text { PF/ pension, gratuity, } \\
\text { health care \& maternity benefits } \\
-7 \text {; not eligible for any of above } \\
\text { Social security benefits }-8 \text {. }\end{array}$ & $\begin{array}{l}\text { Social Security } \\
\text { Benefits Dummy }\end{array}$ & $\begin{array}{l}=1 \text { if receives any kind of } \\
\text { social security benefits } \\
=0 \text { otherwise }\end{array}$ \\
\hline $\begin{array}{l}\text { whether eligible } \\
\text { for paid leave }\end{array}$ & yes -1 , no -2 & $\begin{array}{l}\text { Paid Leave } \\
\text { Eligibility } \\
\text { Dummy }\end{array}$ & $\begin{array}{l}=1 \text { if eligible for paid leave } \\
=0 \text { otherwise }\end{array}$ \\
\hline $\begin{array}{l}\text { Job Contract } \\
\text { Type Dummy }\end{array}$ & $\begin{array}{l}\text { No written job contract-1, written } \\
\text { job contract for one year-2, more } \\
\text { than one year to } 3 \text { years-3, more } \\
\text { than } 3 \text { years }\end{array}$ & Contract dummy & $\begin{array}{l}=1 \text { if more than } 3 \text { years } \\
=0 \text { otherwise }\end{array}$ \\
\hline $\begin{array}{l}\text { Whether } \\
\text { engaged mostly } \\
\text { in full time or } \\
\text { part time work } \\
\text { during last } 365 \\
\text { days }\end{array}$ & full time -1 , part time -2 & $\begin{array}{l}\text { Full } \\
\text { Dummy }\end{array}$ & $\begin{array}{l}=1 \text { if engaged in full time } \\
\text { basis } \\
=0 \text { otherwise }\end{array}$ \\
\hline State & & Region Dummy1 & $=1$ if state: Bihar $^{12}$, Orissa, \\
\hline
\end{tabular}

\footnotetext{
${ }^{12}$ Including Jharkhand for $61^{\text {st }}$ round,
} 


\begin{tabular}{|c|c|c|c|}
\hline \multirow{6}{*}{\multicolumn{2}{|c|}{ Explained clearly in State Codes file of NSS }} & & $\begin{array}{l}\text { West Bengal } \\
=0 \text { otherwise }\end{array}$ \\
\hline & & Region Dummy2 & $\begin{array}{l}=1 \text { if State: Arunachal } \\
\text { Pradesh, Assam, Manipur, } \\
\text { Mizoram, Nagaland, } \\
\text { Sikkim, Tripura } \\
=0 \text { otherwise }\end{array}$ \\
\hline & & \multirow[t]{2}{*}{ Region Dummy3 } & $=1$ if state: Uttar Pradesh ${ }^{13}$, \\
\hline & & & 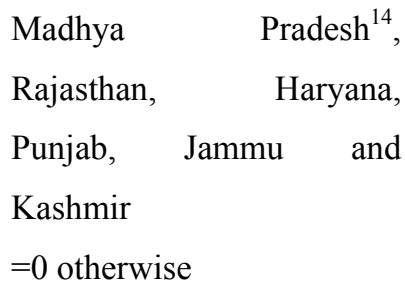 \\
\hline & & Region Dummy4 & $\begin{array}{l}=1 \text { if Gujarat, Dadra \& } \\
\text { Nagar Haveli, Daman \& } \\
\text { Diu, Maharashtra }\end{array}$ \\
\hline & & Region Dummy5 & $\begin{array}{l}=1 \text { if state: Andhra Pradesh, } \\
\text { Pondicherry, Tamil Nadu, } \\
\text { Kerala, Karnataka, } \\
\text { lakhsdeep, Andaman and } \\
\text { Nichobar Island, Goa } \\
=0 \text { otherwise }\end{array}$ \\
\hline Sector & $\begin{array}{l}\text { Rural-1 } \\
\text { Urban-2 }\end{array}$ & sector & $\begin{array}{l}=1 \text { if rural } \\
=0 \text { if urban }\end{array}$ \\
\hline \multirow{4}{*}{\multicolumn{2}{|c|}{ Household-level Variables }} & $N_{h}^{\text {Pub }}$ & $\begin{array}{l}\text { Total number of household } \\
\text { members employed in the } \\
\text { public sector }\end{array}$ \\
\hline & & $N_{h}^{\text {Other }}$ & $\begin{array}{l}\text { Total number of household } \\
\text { members employed in the } \\
\text { unorganized private sector }\end{array}$ \\
\hline & & $N_{h}^{E A R}$ & $\begin{array}{l}\text { Total number of earners in } \\
\text { a family }\end{array}$ \\
\hline & & Household Size & Household Size \\
\hline
\end{tabular}

${ }^{13}$ Including Uttarakhand

${ }^{14}$ Including Chattishgarh 